\section{Detection of sulfites in fresh meat preparation commercialised at retail in Lazio Region}

\author{
Giuseppe Carrabs, ${ }^{1}$ Giorgio Smaldone, ${ }^{2}$ \\ Leonardo Carosielli, ${ }^{3}$ \\ Mariagrazia Girasole, ${ }^{2}$ \\ Marco Iammarino, ${ }^{4}$ \\ Eugenio Chiaravalle ${ }^{4}$ \\ ${ }^{1}$ Local Health Unit, Latina; ${ }^{2}$ Department \\ of Veterinary Medicine and Animal \\ Production, University of Naples \\ Federico II, Naples; ${ }^{3}$ Local Health Unit, \\ Foggia; ${ }^{4}$ Institute for Experimental \\ Veterinary Medicine of Apulia and \\ Basilicata, Foggia, Italy
}

\begin{abstract}
In Europe sulfur dioxide $\left(\mathrm{SO}_{2}\right)$ and sulfites in foods and beverages at concentrations of more than $10 \mathrm{mg} \mathrm{kg}^{-1}$ or $10 \mathrm{mg} \mathrm{L}^{-1}$ expressed as $\mathrm{SO}_{2}$ equivalents are subject to mandatory labelling. In fresh meats the addition of sulfites is not admitted because of their unlawful use to give the product a more attractive appearance. Aim of the study was to detect sulfites in meat product sampled in 19 commercial shops of Lazio Region. In $\mathrm{n}=12$ samples, sulfites were present at different concentrations and no indication for them was reported on the label. Sulfites concentrations ranged from 13.3 to $1278.9 \mathrm{mg} \mathrm{kg}^{-1}$. The results of the present investigation underline the need for better controls by operators, not only under the food information but also in the consumers' health perspective.
\end{abstract}

\section{Introduction}

There is evidence that the prevalence of food allergies and intolerances has increased over the last decades (Kosunen et al., 2002; Marrone et al., 2012; Piccolo et al., 2016), even if their actual prevalence in developed and developing countries is still uncertain (EFSA, 2014).

In the European Union (EU), in order to prevent and manage food adverse reactions and to protect the health of vulnerable consumers, labelling of foods and ingredients with a scientifically proven allergenic or intolerance effect is established by the Regulation (EU) No 1169/2011 (European Commission, 2011). Annex II of this Regulation provides a detailed list of these substances that include sulfiting agents.
Sulfites are a group of compounds composed by sulfur dioxide and several inorganic sulfite salts that may liberate $\mathrm{SO}_{2}$ under appropriate conditions. They are usually added in a large variety of foodstuffs and beverages (fish, potatoes, wine, dried fruits, etc.) to prevent oxidation and bacterial growth (Taylor et al., 1986) and then to prolong shelf-life. Sulfites can also enhance food appearance by inhibiting discoloration (Ruiz-Capillas and Jiménez-Colmenero, 2009) due inhibiting enzymatic and Maillard-type browning reactions (Vandevijvere et al. 2010).

However the ingestion of sulfite-containing foods may cause allergic reaction and food intolerance symptoms in sensitive individuals (Taylor et al., 1986), such as asthmatic reactions and bronchospasm, occasionally severe, hives, flushing, bradycardia, as well as prominent gastrointestinal symptoms (Schwartz, 1983). Moreover, sulfites may affect the nutritional quality of food by interacting with some vitamins (such as thiamine, folic acid, pyridoxal and nicotiamide) promoting their degradation (Pizzoferrato et al., 1990).

An acceptable daily intake (ADI) of sulfites (expressed as $\mathrm{SO}_{2}$ ) has been defined as $0.7 \mathrm{mg} \mathrm{kg} \mathrm{kg}^{-1}$ body weight (FAO/WHO, 2007). In European Union, Directive 95/2/EC (European Commission, 1995) and Directive 2006/52/EC (European Commission, 2006) fix maximum levels of sulfites for several foods and beverages expressed as $\mathrm{SO}_{2}$ equivalents in $\mathrm{mg} \mathrm{kg}^{-1}$ or

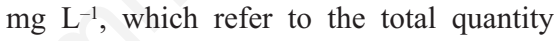
available from all sources. Moreover, Regulation (EC) No 1169/2011 (European Commission, 2011) lays down that sulfur dioxide and sulfites in foods and beverages at concentrations of more than $10 \mathrm{mg} \mathrm{kg}^{-1}$ or $10 \mathrm{mg} \mathrm{L}^{-1}$ are subjected to mandatory labelling.

In fresh meat preparations, the addition of sulfites to preserve the product appearance is prohibited. Therefore, the value of $10 \mathrm{mg} \mathrm{kg}^{-1}$ may be considered as a maximum residual limit (MRL). This latter value could be exceeded if, for example, white wine or other ingredients containing sulfites are present in the food formulation. So, a fresh meat preparation could show relatively high level of sulfites even though it has never been treated with sulfiting agents.

The aim of the present paper was the detection of sulfiting agents in some fresh meat preparations (hamburger and sausages) and to propose a maximum allowable limit for sulfiting agents taking into account that their addition is illegal but, due to use of some ingredients or because of matrix degradation, a residual amount can be found.
Correspondence: Giorgio Smaldone, Department of Veterinary Medicine and Animal Production, University of Naples Federico II, 80137 Naples, Italy.

Tel: +390812536082 .

E-mail: giorgio.smaldone@unina.it

Key words: Sulfites; Fresh meat preparations; EU regulations.

Conflict of interest: the authors declare no potential conflict of interest.

Received for publication: 16 December 2016. Revision received: 7 February 2017.

Accepted for publication: 13 February 2017.

This work is licensed under a Creative Commons Attribution-NonCommercial 4.0 International License (CC BY-NC 4.0).

CCopyright G. Carrabs, et al., 2017

Licensee PAGEPress, Italy

Italian Journal of Food Safety 2017; 6:6482

doi:10.4081/ijfs.2017.6482

\section{Materials and Methods}

Experimental tests were carried out on 38 samples of fresh minced meat preparations (pork's hamburger and sausages) collected at retail during the official controls in 19 stores of Lazio Region.

The screening-qualitative analyses were performed by using AOAC method for sulfites in meats (AOAC, 1995). In particular, 10 grams of homogenised sample were placed in a test tube with $10 \mathrm{~mL}$ of distilled water. Then, $2.5 \mathrm{~mL}$ of $\mathrm{H}_{2} \mathrm{SO}_{4}$ were added and the whole solution was heated in a water bath at $70^{\circ} \mathrm{C}$. The test tube was sealed by interposing a strip of adsorbent paper, previously soaked in a solution of malachite green, between the cap and the glass. A discoloration of the paper occurring within a maximum time of 30 minutes indicated the presence of sulfiting agents at concentrations higher than $10 \mathrm{mg} \cdot \mathrm{kg}^{-1}$ (expressed as $\mathrm{SO}_{2}$ ) (LOQ).

The positive samples at the screening analysis were confirmed by an ion exchange chromatographic method (Iammarino et al., 2010) to obtain quantitative evaluations. According to this confirmatory test, a 4-g portion of the homogenised sample was mixed with $40 \mathrm{~mL}$ of a stabilising solution containing $50 \mathrm{mM} \mathrm{NaOH}, 10 \mathrm{mM}$ fructose and $0.1 \mathrm{M}$ EDTA in a horizontal shaker for $30 \mathrm{~min}$. After centrifugation for $5 \mathrm{~min}$ at $250 \times \mathrm{g}$ at room temperature, $2 \mathrm{~mL}$ of supernatant were filtered through Anotop 10 LC (0.2 $\mu \mathrm{m}, 10 \mathrm{~mm}$, Whatman) before being submit- 
ted to chromatographic analysis.

Chromatographic separations were performed on a Dionex system (Dionex Corporation, Sunnyvale, CA, USA) composed of a GP50 quaternary gradient pump, an electrochemical detector (model ED40) set to conductivity mode, equipped with a temperature compensated conductivity cell, and a Rheodyne injection valve (model RH9125, Cotati, CA, USA) with a $25 \mu \mathrm{L}$ injection loop. A Dionex anion self-regenerating suppressor (ASRS II, 4mm) was used for the electrochemical suppression, at an operating current of $50 \mathrm{~mA}$. All the separations were performed using an IonPac AS9HC column $(250 \mathrm{~mm} \times 4 \mathrm{~mm}$ i.d., particle size: $9 \mu \mathrm{m}$ ) eluted in gradient mode at a flow rate of $1.0 \mathrm{mLmin}^{-1}$. The mobile phase consisted of $8 \mathrm{mM} \mathrm{Na}_{2} \mathrm{CO}_{3}$ and $2.3 \mathrm{mM}$ $\mathrm{NaOH}$ (A) and $24 \mathrm{mM} \mathrm{Na}_{2} \mathrm{CO}_{3}$ (B). The solvent gradient program started with an isocratic step at $100 \% \mathrm{~A}$ for $15 \mathrm{~min}$, a gradient step to $50 \% \mathrm{~A}$ and $50 \% \mathrm{~B}$ in $1 \mathrm{~min}$, and then $4 \mathrm{~min}$ at this eluent concentration. Finally, the system was re-equilibrated for $20 \mathrm{~min}$ at $100 \%$ A. The plastic reservoir bottles (DX500 2 L bottles, Dionex) were closed and pressurised with pure nitrogen to 0.8 $\mathrm{MPa}$. The system was interfaced, via proprietary network chromatographic software (PeakNetTM), to a personal computer for instrumentation control, data acquisition and processing (Dionex).

\section{Results and Discussion}

Results are reported in Tables 1 and 2 . The samples positive to the screening test $\left(\left[\mathrm{SO}_{2}\right]>10.0 \mathrm{mg} \mathrm{kg}^{-1}\right.$ (LOQ)) were 12 $(31.6 \%)$ (6 hamburgers and 6 sausages). These samples were collected from 11 of the 19 total shops. The quantitative determinations of sulfite content in these suspected positive samples were carried out by ion chromatography. These analytical determinations revealed sulfite concentrations ranging from 35 to $1278.9 \mathrm{mg} \mathrm{kg}^{-1}$. Each result was the mean of n. 3 replications.

On the basis of the obtained results, samples were divided into two groups: a group $A$ of 7 samples (4 hamburgers and 3 sausages) with sulfite concentrations lower than $35 \mathrm{mg} \mathrm{kg}^{-1}$ and a group $B$ of 5 samples ( 2 hamburger and 3 sausages) with sulfite concentrations higher than $200 \mathrm{mg} \mathrm{kg}{ }^{-1}$ (Table 2).

The high sulfite concentrations $(>200$ $m g \mathrm{~kg}^{-1}$ ) found in the samples belonging to group $B$ can be attributable to illegal sulfiting agent addition. On the contrary, fraudulent use of sulfiting agents for samples belonging to group $A$ seems unlikely. In fact, at this concentrations $\left(<35 \mathrm{mg} \mathrm{kg}^{-1}\right)$, sulfites would not play an effective antioxidant, antimicrobial or blanching activity (Iammarino et al., 2012). Therefore, the presence of such residues is, in this case, more probably due to a carry-over effect or it could be the result of the addition of some particular ingredients containing sulfites

(e.g. white wine). As demonstrated by some authors (Iammarino et al., 2012), the presence of low sulfite concentrations in fresh meat preparations could also be attributable to the reduction, by sulfate-reducing bacteria, of free sulfates naturally present in fresh meat (Jay et al., 2005).

Table 1. Results obtained on the analysed fresh meat preparations.

\begin{tabular}{|c|c|c|}
\hline Commercial retailer & Samples & Mean \pm SD $\left(\mathrm{mg} \mathrm{kg}^{-1}\right)$ \\
\hline 1 & $\begin{array}{l}\text { Hamburger } \\
\text { Sausages }\end{array}$ & $\begin{array}{l}\text { nd } \\
\text { nd }\end{array}$ \\
\hline 2 & $\begin{array}{l}\text { Hamburger } \\
\text { Sausages }\end{array}$ & $\begin{array}{l}487 \pm 6.45 \\
367 \pm 6.26\end{array}$ \\
\hline 3 & $\begin{array}{l}\text { Hamburger } \\
\text { Sausages }\end{array}$ & $\begin{array}{c}1278.9 \pm 15.66 \\
\text { nd }\end{array}$ \\
\hline 4 & $\begin{array}{l}\text { Hamburger } \\
\text { Sausages }\end{array}$ & $\begin{array}{c}\text { nd } \\
231.3 \pm 3.66\end{array}$ \\
\hline 5 & $\begin{array}{l}\text { Hamburger } \\
\text { Sausages }\end{array}$ & $\begin{array}{l}\text { nd } \\
\text { nd }\end{array}$ \\
\hline 6 & $\begin{array}{c}\text { Hamburger with red chicory } \\
\text { Hamburger } \\
\text { Sausages }\end{array}$ & $\begin{array}{l}14.7 \pm 1.05 \\
\text { nd } \\
\text { nd }\end{array}$ \\
\hline 7 & $\begin{array}{l}\text { Hamburger } \\
\text { Sausages }\end{array}$ & $\begin{array}{c}19.3 \pm 1.68 \\
\text { nd }\end{array}$ \\
\hline 8 & $\begin{array}{l}\text { Hamburger } \\
\text { Sausages }\end{array}$ & $\begin{array}{c}28.1 \pm 2.65 \\
\text { nd }\end{array}$ \\
\hline 9 & $\begin{array}{l}\text { Hamburger } \\
\text { Sausages }\end{array}$ & $\begin{array}{l}\text { nd } \\
\text { nd }\end{array}$ \\
\hline 10 & $\begin{array}{l}\text { Hamburger } \\
\text { Sausages }\end{array}$ & $\begin{array}{c}\text { nd } \\
255.7 \pm 3.68\end{array}$ \\
\hline 11 & $\begin{array}{l}\text { Hamburger } \\
\text { Sausages }\end{array}$ & $\begin{array}{c}\text { nd } \\
34.1 \pm 2.59\end{array}$ \\
\hline 12 & $\begin{array}{l}\text { Hamburger } \\
\text { Sausages }\end{array}$ & $\begin{array}{c}\text { nd } \\
34.1 \pm 3.09\end{array}$ \\
\hline 13 & $\begin{array}{l}\text { Hamburger } \\
\text { Sausages }\end{array}$ & $\begin{array}{l}\text { nd } \\
\text { nd }\end{array}$ \\
\hline 14 & $\begin{array}{l}\text { Hamburger } \\
\text { Sausages }\end{array}$ & $\begin{array}{c}\text { nd } \\
19.5 \pm 2.33\end{array}$ \\
\hline 15 & Sausages & nd \\
\hline 16 & $\begin{array}{l}\text { Hamburger } \\
\text { Sausages }\end{array}$ & $\begin{array}{c}13.3 \pm 3.24 \\
\text { nd }\end{array}$ \\
\hline 17 & $\begin{array}{l}\text { Hamburger } \\
\text { Sausages }\end{array}$ & $\begin{array}{l}\text { nd } \\
\text { nd }\end{array}$ \\
\hline 18 & $\begin{array}{l}\text { Hamburger } \\
\text { Sausages }\end{array}$ & $\begin{array}{l}\text { nd } \\
\text { nd }\end{array}$ \\
\hline 19 & $\begin{array}{c}\text { Hamburger } \\
\text { Sausages }\end{array}$ & $\begin{array}{l}\text { nd } \\
\text { nd }\end{array}$ \\
\hline
\end{tabular}

SD, standard deviation; nd, not detected.

Table 2. Results obtained on the analysed fresh meat preparations and grouped according to the concentration.

\begin{tabular}{lccc} 
Samples & $\begin{array}{c}\text { Screened } \\
\text { samples }\end{array}$ & $\left(\mathbf{1 0} .0<\left[\mathrm{SO}_{2}\right]<35 \mathrm{mg} \mathrm{kg}^{-1}\right)$ & $\begin{array}{c}\text { Group B } \\
\text { Hamburger }\end{array}$ \\
Sausages & 19 & 4 & 2 \\
Total & 19 & 3 & 3 \\
\hline
\end{tabular}




\section{Conclusions}

From a survey of 38 fresh meat preparations, quantifiable sulfite concentrations were found in 12 samples. In 7 of these samples (18\% of total samples), sulfite concentrations were lower than $35 \mathrm{mg} \mathrm{kg}^{-1}$, whereas the remaining 5 samples $(13 \%$ of total samples) showed sulfite concentrations ranging from 200 to $1278.9 \mathrm{mg} \mathrm{kg}^{-1}$, probably as a consequence of fraudulent sulfiting agents addition. The high percentage of samples with sulfite levels higher than $200 \mathrm{mg} \mathrm{kg}^{-1}$ suggests that adulteration of fresh meat preparations by means of sulfite addition is still a relatively common practice and, considering the adverse effects of these additives, more effective control measures are needed. On the basis of the distribution of sulfite concentrations found in the positive samples and taking into account the results of previous studies (Iammarino et al., 2012), we suggest $40 \mathrm{mg} \mathrm{kg}^{-1}$ (expressed as $\mathrm{SO}_{2}$ ) as the maximum allowable limit of sulfites in fresh meat preparations above which the use should be considered illegal. In any case, the mandatory labelling for sulfite concentrations higher than $10 \mathrm{mg} \mathrm{kg}^{-1}$ (as established by the Regulation (EC) N. 1169/2011; European Commission, 2011) would be still valid.

\section{References}

AOAC, 1995. Official Methods of Analysis. Sulfites in meats: qualitative test, no. 961.09. Official methods of analysis. AOAC official method 990.28. Sulfites in foods. Optimized Monier-Williams Method. AOAC, Rockville, MD, USA.

European Commission, 1995. Directive 95/2/EC. European Parliament and Council Directive of 20 February 1995 on food additives other than colours and sweeteners. In: Official Journal, L 61, 18/03/1995, pp. 1-40.

European Commission, 2006. Directive of 12 April 2006 opening a tendering procedure for the sale of wine alcohol for use as bioethanol in the Community 52/2006/EC. In: Official Journal, L 104/15, 13.4.2006.

European Commission, 2011. Council Regulation of 25 October 2011 on the provision of food information to consumers, amending Regulations (EC) No $1924 / 2006$ and (EC) No 1925/2006 of the European Parliament and of the Council, and repealing Commission Directive 87/250/EEC, Council Directive 90/496/EEC, Commission Directive 1999/10/EC, Directive 2000/13/EC of the European Parliament and of the Council, Commission Directives 2002/67/EC and 2008/5/EC and Commission Regulation (EC) No 608/2004, 1169/2011/EC. In: Official Journal, L 304/18, 22.11.2011.

EFSA, 2014. Scientific opinion on the evaluation of allergenic foods and food ingredients for labelling purposes. EFSA J 12:3894.

FAO/WHO, 2007. Summary of evaluations performed by the Joint FAO/WHO Expert Committee on Food Additives. Sulfur dioxide. Food and Agriculture Organization/World Health Organization, Rome, Italy and Geneva, Switzerland.

Iammarino M, Di Taranto M, Muscarella $\mathrm{M}, 2012$. Investigations on the presence of sulfites in fresh meat preparations: estimation of an allowable maximum limit. Meat Sci 90:304-8.

Iammarino M, Di Taranto A, Muscarella M, Nardiello D, Palermo C, Centonze D, 2010. Development of a new analytical method for the determination of sulfites in fresh meats and shrimps by ionexchange chromatography with con- ductivity detection. Anal Chim Acta 672:61-5.

Jay JM, Loessner MJ, Golden DA, 2005. Modern food microbiology (7th ed.) Springer Science and Business Media, New York, NY, USA.

Kosunen TU, Hook-Nikanne J, Salomaa A, Sarna S, Aromaa A and Haahtela T, 2002. Increase of allergen-specific immunoglobulin $\mathrm{E}$ antibodies from 1973 to 1994 in a Finnish population and a possible relationship to Helicobacter pylori infections. Clin Exp Allergy 32:373-8.

Marrone R, Vollano L, Smaldone G, Anastasio A, 2012. Detection of allergens in food products commercialized in Italy. Emir J Food Agric (in press).

Piccolo F, Vollano L, Base G, Girasole M, Smaldone G, Cortesi ML, 2016. Research of soybean and lactose in meat products and preparations sampled at retail. Ital J Food Safety 5:5780.

Pizzoferrato L, Quattrucci E, Di Lullo G, 1990. Evaluation of an HPLC method for the determination of sulfiting agents in foods. Food Add Contam 7:189-95.

Ruiz-Capillas C, Jiménez-Colmenero F, 2009. Application of flow injection analysis for determining sulfites in food and beverages: a review. Food Chem 112:487-93.

Schwartz HJ, 1983. Sensitivity to ingested metabisulfite: variations in clinical presentation. J Allergy Clin Immunol 71:487-9.

Taylor SL, Higle NA, Bush RK, 1986. Sulfites in foods: Uses, analytical methods, residues, fate, exposure assessment, metabolism, toxicity, and hypersensitivity. Adv Food Res 30:1-76.

Vandevijvere S, Temme E, Andjelkovic M, De Wil M, Vinkx C, Goeyens L, Van Loco J, 2010. Estimate of intake of sulfites in the Belgian adult population. Food Add Contam 27:1072-83. 